SINAI Journal of Applied Sciences 10 (3) $2021 \quad 521-534$

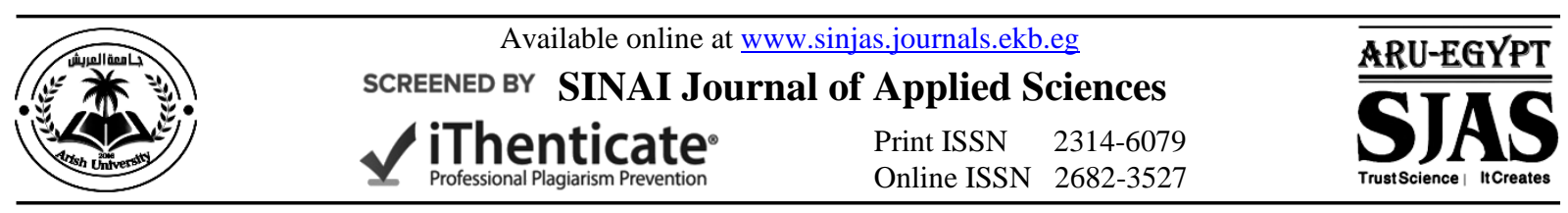

\title{
AN ECONOMIC STUDY OF PRODUCTION AND COSTS OF OLIVE CROP IN NORTH SINAI GOVERNORATE
}

\author{
Ahmed F. Nofal $^{1}$; M.A. ElSayed ${ }^{1}$; R.I. Redwan ${ }^{1}$; R.M. Hefny ${ }^{1}$ and M.M. El-Batran $^{2}$ \\ 1. Dept. Econ. and Rural Develop., Fac. Environ. Agric. Sci., Arish Univ., Egypt. \\ 2. Dept. Agric. Econ., Fac. Agric., Cairo Univ., Egypt.
}

\begin{tabular}{l} 
ARTICLE INFO \\
\hline Article history: \\
Received: $28 / 08 / 2021$ \\
Revised: $09 / 10 / 2021$ \\
Accepted: $22 / 12 / 2021$ \\
Available online: $22 / 12 / 2021$ \\
\hline Keywords: \\
Tangerine crop, \\
economic study, \\
production functions, \\
cost functions, \\
North Sinai Governorate
\end{tabular}

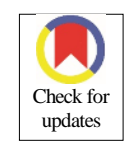

\begin{abstract}
Olive crop is one of the important fruit crops, and it is conceder an important nutritional component, used to extract the best nutritional and healthful vegetable oils, as olive oil is called green gold. North Sinai Governorate is one of the promising governorates for olive production, as this crop occupies the first rank in the list of crop composition for horticultural crops. The research aims to study the productive and economic efficiency, evaluate the performance of olive farms, During the study of the results, the average total area in Egypt reached about 184.6 thousand feddans during the period 20002017. The average area of the fruit trees was about 137,1 thousand feddans, the average productivity per acre was about 4.1 ton, and the average total production was about 557.3 thousand ton. When studying the relative importance of olives in North Sinai Governorate during 2017, it was found that the average fruitful area in Bir El-Abed was about 6.7 thousand feddans, in Rafah it amounted to 5.1 thousand feddans, and in Sheikh Zuweid amounted to 4.6 thousand feddans. In El-Arish amounted to 10.2 thousand feddans, in Al-Hasana amounted to about 1.9 thousand feddans, and in Nakhl amounted to 0.59 thousand feddans. As for the total sample, it amounted to 28.96 thousand feddans, and the statistical estimate of the production functions and costs of the olive crop was studied within the various tenure categories. The research also recommends replace large and low-yielding trees, planting disease-resistant varieties.
\end{abstract}

$$
\begin{aligned}
& \text { و الاقتصسادية، وتقييم أداء المزار ع الزيتونيـة في محافظـة }
\end{aligned}
$$

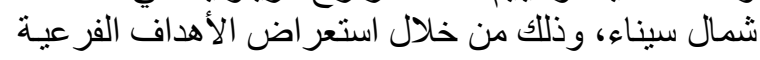

$$
\begin{aligned}
& \text { التالبة: } \\
& \text { 1. استعر اض الوضع الر اهن لمحصول الزيتون في مصر. } \\
& \text { 2. اسـتعر اض الوضـع الـر اهن لمحصــول الزيتـون داخل } \\
& \text { محافظة شمال سيناء. } \\
& \text { 3. تقدير الـدوال الإنتاجيـة ومؤشـرات الكفــاءة الإنتاجيـة }
\end{aligned}
$$

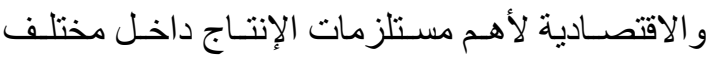

$$
\begin{aligned}
& \text { الفئات الحيازية بعينة الدر اسة بمحافظة شمال سيناء. } \\
& \text { 4. التحليـل الاقتصـادي لتكـاليف انتـاج محصـول الزيتون، التون. }
\end{aligned}
$$

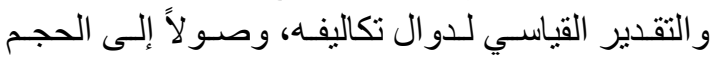

$$
\begin{aligned}
& \text { الأمثتل و الحجـوم المعظمـة للأربــاح، وتقـدير الـدخل } \\
& \text { الضائع داخل المزارع الإنتاجية محافظة شمال سيناء. }
\end{aligned}
$$

\section{المقدمة والمشكلة البحثية}

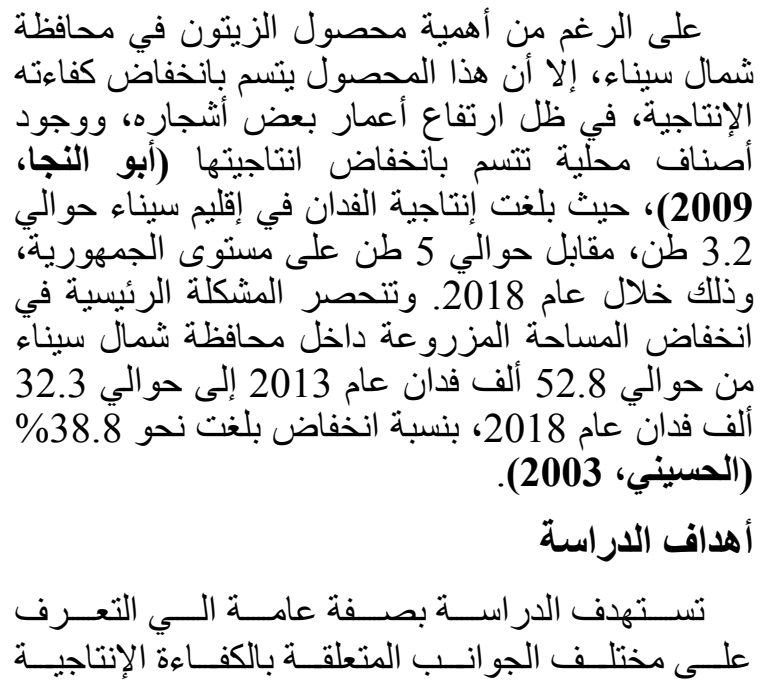

\footnotetext{
* Corresponding author: E-mail address: ahmedfouad@yahoo.com https://doi.org/10.21608/sinjas.2021.93060.1045

(C) 2021 SINAI Journal of Applied Sciences. Published by Fac. Environ. Agric. Sci., Arish Univ. All rights reserved.
} 
الزيتون في مصر خـلال الفترة 2000- 2017، حيث يتبين

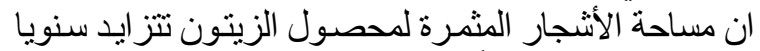

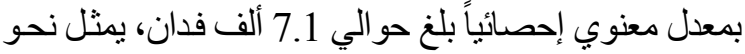
5.2 0 5ن المتوسط العام خلال تلألك الفترة.

\section{الإتتاجية الفدانية لمحصول الزيتون}

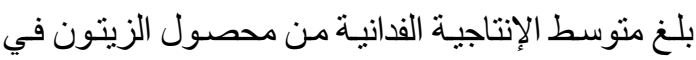

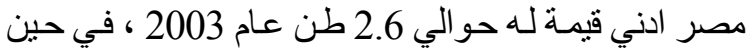

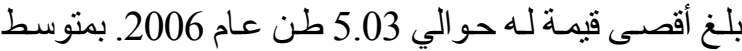

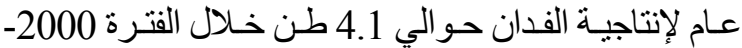

ويتضـح مـن المعادلـة رقـم (3) بجـدول 2 أن الإنتاجيـة

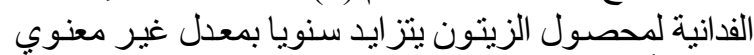

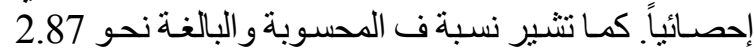
الي مدي مطابقة النموذج المستخدم لطييعة الييانات موضع

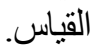

\section{تطور الإنتاج الكلي لمحصول الزيتون}

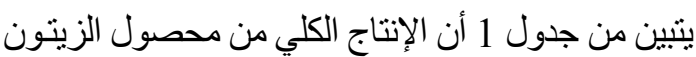

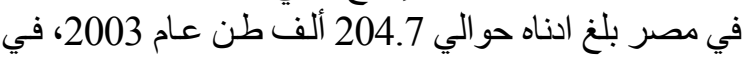

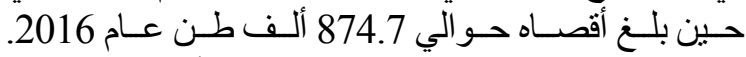

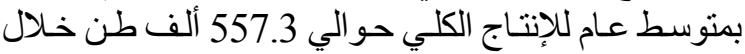
الفترة 2000 -2017. ويتضح من المئر المعادلة رقم 4 بجدول 2

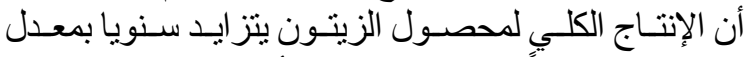

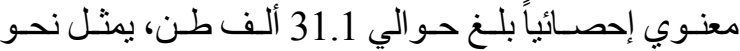
5.6\% من المتوسط العام خلال تلك الفترة.

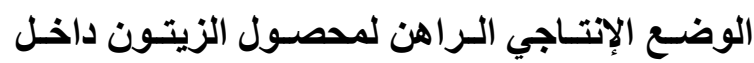

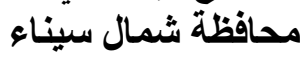

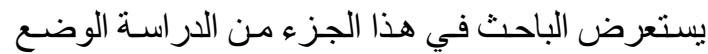

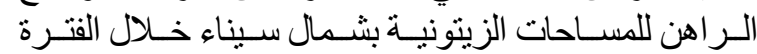

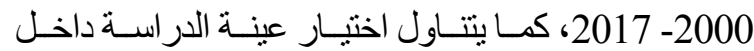

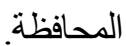

الأهميـة النسبية لمحصول الزيتهون داخل محاصيل

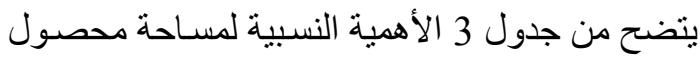

الزيتون بين محاصيل الفاكهة في محافظـة شـمال سيناء

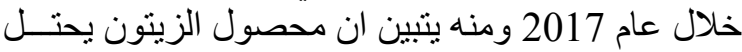

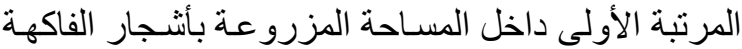

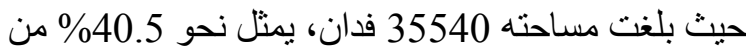

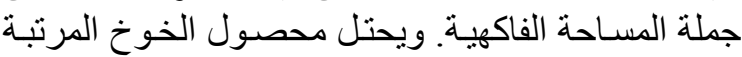

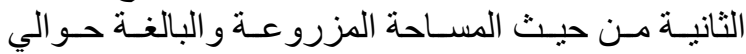

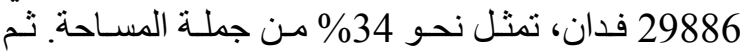

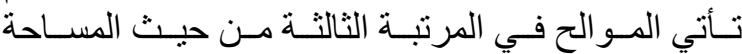
المزرو عة و البالغة حو الي 8679 فدان، تمثل نحو

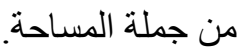

\section{مصادر البيانات والطريقة البحثية}

اعتمد الباحث في تحقيق أهداف الدر اسة على البيانات

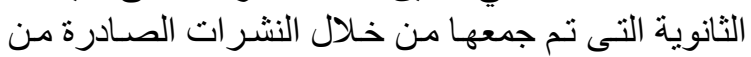

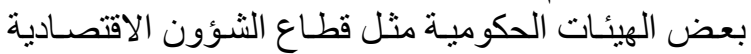

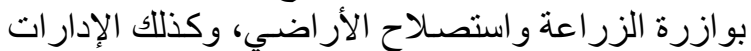

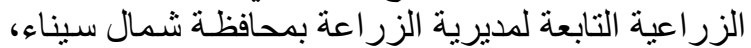

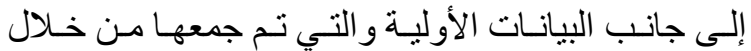

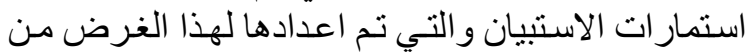

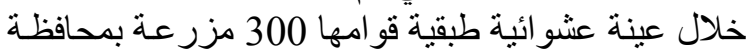

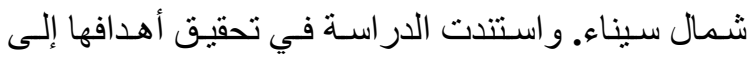

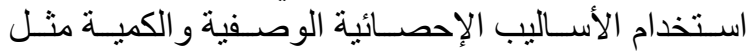

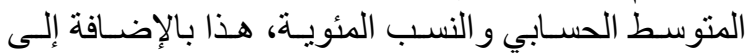

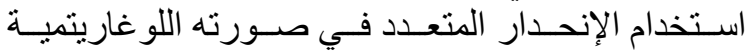

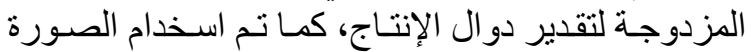
التكعيبية لتقدير دو ال التكاليف.

\section{الوضع الإنتاجي لمحصول الزيتون في مصر}

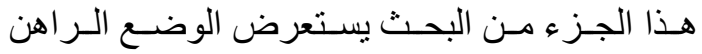

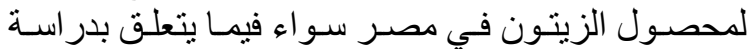
المؤشر ات الإنتاجية لمحصول الزينون فئون وذللك خلال الفترة

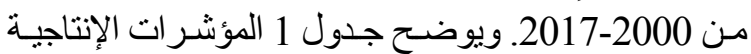

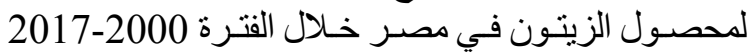
ومنه ينبين أن: - الزئون

\section{تطور المساحة الكلية من محصول الزيتون}

يتبين من الأرقام الواردة بجدول 1 ان المسـاحة الكليـة

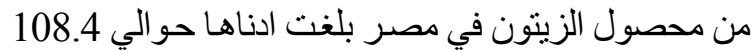

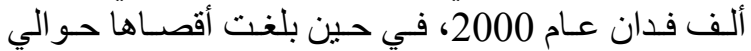
243.2 ألف فدان عام 2016. بمتوسط عام للمساحة الكلية

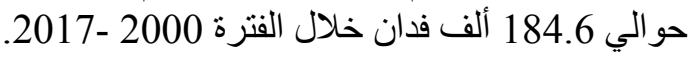
يتضح من جدول 2 نتائج تقدير معادلة الاتجاه الزمني لمني

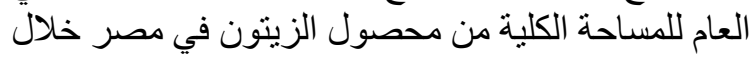

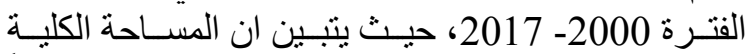
لمحصول الزيتون تنز ايد سنويا بمعدل يثل معنوي إحصـائياً

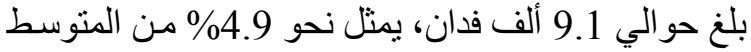

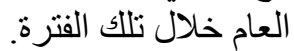

تطور مساحة الأثجار المثمرة من محصول الزيتون

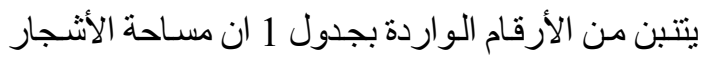

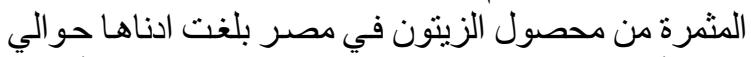

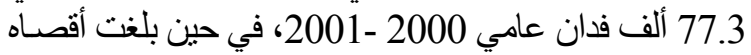
حو الي 218.5 ألف فذان عام 2017. بمتوسط عام لمان لمساحة

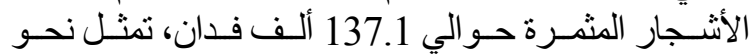

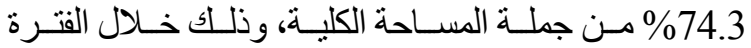
2000- 2017. وينضـح مـن جدول 2 نتائج نقدير معادلـة

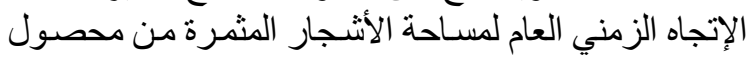


Nofal, et al. | SINAI Journal of Applied Sciences 10 (3) $2021521-534$

جدول 1. المؤشرات الإنتاجية لمحصول الزيتون في مصر خلال الفترة 2000- 2017

\begin{tabular}{|c|c|c|c|c|}
\hline الألفتاج طن الكلي & م. طن/ فيدة الفدان & مساحة الأثخجار المثرة & ألفـاحة فان الكلية & السنة \\
\hline 281.7 & 3.64 & 77.3 & 108.4 & 2000 \\
\hline 293.9 & 3.80 & 77.3 & 113.1 & 2001 \\
\hline 336.4 & 4.19 & 80.4 & 117.9 & 2002 \\
\hline 204.7 & 2.61 & 78.6 & 118.7 & 2003 \\
\hline 315.2 & 3.89 & 81.1 & 116.8 & 2004 \\
\hline 314.5 & 3.25 & 96.8 & 118.4 & 2005 \\
\hline 544.6 & 5.03 & 108.3 & 125.4 & 2006 \\
\hline 507.1 & 4.58 & 110.8 & 135.7 & 2007 \\
\hline 480.1 & 4.37 & 109.9 & 150.3 & 2008 \\
\hline 449.0 & 4.08 & 110.2 & 158.1 & 2009 \\
\hline 390.9 & 3.27 & 119.4 & 163.3 & 2010 \\
\hline 459.7 & 3.67 & 125.4 & 155.8 & 2011 \\
\hline 563.1 & 4.11 & 137.0 & 202.7 & 2012 \\
\hline 541.8 & 3.69 & 146.9 & 240.5 & 2013 \\
\hline 565.7 & 3.91 & 144.9 & 237.4 & 2014 \\
\hline 698.9 & 4.21 & 165.9 & 227.7 & 2015 \\
\hline 874.7 & 4.65 & 187.9 & 243.2 & 2016 \\
\hline 854.7 & 5.01 & 218.5 & 241.9 & 2017 \\
\hline 557.3 & 4.14 & 137.1 & 184.6 & المتوسط العام \\
\hline
\end{tabular}

المصدر: وزارة الزراعة واستصلاح الاراضي، قطاع الثشئون الاقتصادية، نثرة المساحة المحصولية، أعداد متفرقة.

جدول 2. معادلات الاتجاه الزمنى العام لتظور المساحة والإتتاج الكلي والإنتاجية لمحصول الزيتون في مصر خلال الفترة 2017-2000

\begin{tabular}{|c|c|c|c|c|}
\hline $\bar{F}$ & التغير النسنوى معدل & المعادلات & المتغيرات الإنتاجية & المعادلة \\
\hline${ }^{* * *} 131.2$ & 4.9 & $\begin{array}{l}\hat{\mathbf{Y}}=78.03+9.1 \mathbf{T}_{\mathbf{i}} \\
(8.9)^{* *} \quad(11.4)^{* *}\end{array}$ & (ألف فاحة الكلية & 1 \\
\hline${ }^{* * *} 130.3$ & 5.2 & $\begin{array}{l}\hat{\mathbf{Y}}=53.41+7.1 \mathbf{T}_{\mathbf{i}} \\
(7.9)^{* *} \quad(11.4)^{* *}\end{array}$ & مساحة الأشجار المثرة & 2 \\
\hline 2.87 & 1.1 & $\begin{array}{c}\hat{\mathbf{Y}}=3.56+0.045 \mathbf{T}_{\mathbf{i}} \\
(12.3)^{* *}(1.6)\end{array}$ & م. انتاجية الفدان & 3 \\
\hline${ }^{* *} 56.1$ & 5.6 & $\begin{array}{c}\hat{\mathbf{Y}}=186.8+31.07 \mathbf{T}_{\mathbf{i}} \\
(4.2)^{* *} \quad(7.5)^{* *}\end{array}$ & الألتتاج الكلي & 4 \\
\hline
\end{tabular}

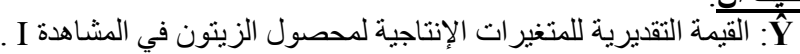

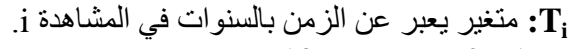
18 ................ ، 2 ، 1 ، 1 = I المصدر: جُمعت وحُسبت من الأرقام الواردة بالجدول رقم 1. 
جدول 3. الأهمية النسبية لمساحة محصول الزيتون بين محاصيل الفاكهة في محافظة شمال سيناء خلال عام 2017

\begin{tabular}{|c|c|c|}
\hline الأهمية النسبية (\%) & المساحة المزروعة (فدان) & المحاصيل \\
\hline 40.47 & 35540 & زيتون \\
\hline 34.03 & 29886 & خوخ \\
\hline 9.88 & 8679 & موالح \\
\hline 9.52 & 8356 & 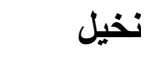 \\
\hline 2.24 & 1971 & 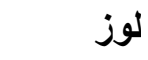 \\
\hline 1.27 & 1112 & 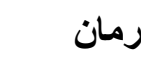 \\
\hline 0.80 & 706 & تين \\
\hline 0.60 & 524 & تفاح \\
\hline 0.53 & 465 & 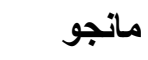 \\
\hline 0.33 & 294 & عنب \\
\hline 0.18 & 157 & جوافة \\
\hline 0.13 & 116 & كمثري \\
\hline 0.01 & 6 & مشمش \\
\hline$*$ & 3 & فستق \\
\hline 100 & 87815 & الاجمالي \\
\hline
\end{tabular}

الأدنى حو الي 2.6 ألف فدان عام 2004، في حين بلغت هذان

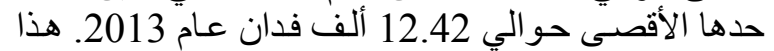

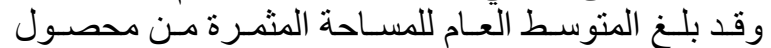
الزيتون داخل مركز بئر العبد حو الي 6.7 ألف فئل فدان، يمثل نحو 23.1\% من جملة المحافظة.

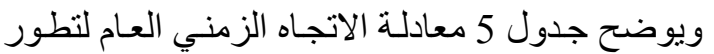
المساحة المثمرة داخل مركز بئر العبد خلال منتوسط الفئ الفترة

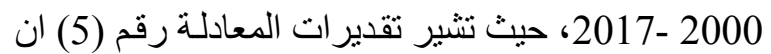
المساحة المثمرة من محصول الزيتون تتز ايد سنويا بمقدار

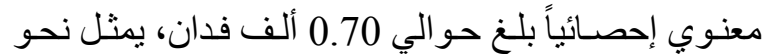
10.5\% من المتوسط العام خلال نفس الفترة.

$$
\text { تطور المساحة المثمرة لمركز رفح }
$$

يتبين من الأرقام الواردة بجدول 4 أن المساحة المثمرة

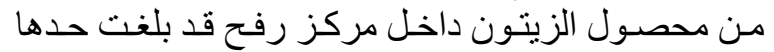

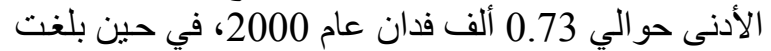

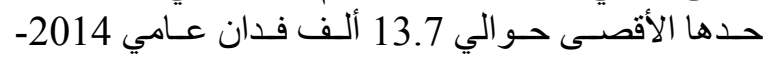

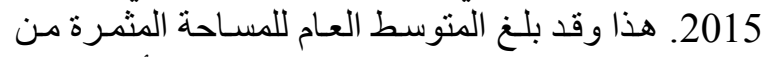
محصول الزيتون داخل مركز رفح حو الي 5.1 ألف فدان، يمثل نحو 17.5\% من جملة المحافظة.
ثم يأني محصول النخيل في المرتبـة الر ابعة من حيث

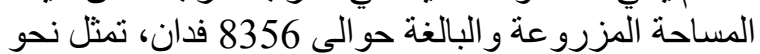

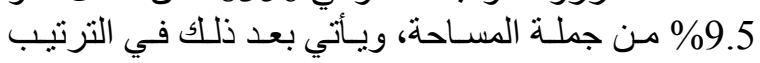

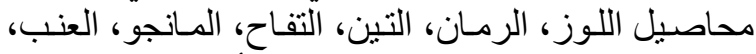
الجو افة، الكمثري، المشمش، الفستق * بأهميـة نسبية بلغت النت

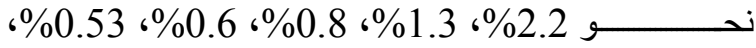

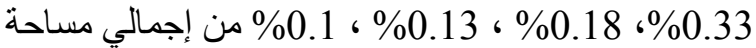

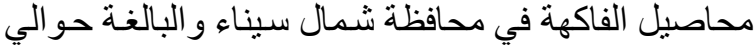

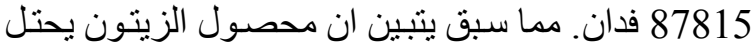

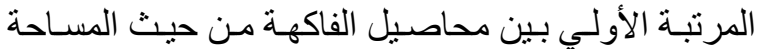

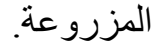

تطور المساحة المثمرة لمحصول الزيتون في محافظة

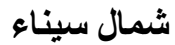

يتضح من جدول 4 نطور المساحات المثمرة لمحصول المدارل الزيتون داخل مختلف المر اكز الإداريـة بمحافظــة شمال سيناء خلال الفترة 2000-2017 ومنه يتبين أن : تطور المساحة المثمرة لمركز بئر العبد

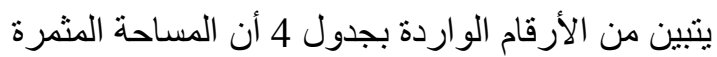
من محصول الزيتون داخل مركز بئر العبد قد بلغت حدها لئها 
جلول 4. تطور المساحات المثمرة لمحصول الزيتون داخل مختلف المراكز الإدارية بمحافظة شمال سيناء خلال الفترة المساحة: ألف فدان فلان

$2017-2000$

\begin{tabular}{|c|c|c|c|c|c|c|c|}
\hline جملة & نخل & الحسنة & العريش & الثيخ زويد & رفح & بئر العبد & السنوات \\
\hline 12.10 & 0.33 & 0.92 & 5.78 & 1.68 & 0.73 & 2.66 & 2000 \\
\hline 12.54 & 0.36 & 0.98 & 5.91 & 1.86 & 0.85 & 2.58 & 2001 \\
\hline 12.97 & 0.38 & 0.92 & 6.00 & 2.02 & 0.85 & 2.80 & 2002 \\
\hline 13.39 & 0.49 & 1.10 & 6.09 & 2.02 & 0.85 & 2.84 & 2003 \\
\hline 13.85 & 0.49 & 1.17 & 6.26 & 2.51 & 0.87 & 2.55 & 2004 \\
\hline 14.25 & 0.49 & 1.09 & 6.42 & 2.78 & 0.87 & 2.60 & 2005 \\
\hline 14.61 & 0.49 & 1.09 & 6.47 & 2.97 & 0.87 & 2.72 & 2006 \\
\hline 15.96 & 0.47 & 1.09 & 6.65 & 3.59 & 0.88 & 3.28 & 2007 \\
\hline 34.31 & 0.41 & 3.10 & 15.93 & 4.85 & 3.78 & 6.24 & 2008 \\
\hline 36.75 & 0.38 & 3.26 & 16.56 & 5.47 & 3.99 & 7.09 & 2009 \\
\hline 27.8 & 0.43 & 3.24 & 12.42 & 2.49 & 1.44 & 7.78 & 2010 \\
\hline 30.04 & 0.50 & 2.24 & 14.10 & 3.28 & 2.06 & 7.86 & 2011 \\
\hline 43.47 & 0.55 & 1.89 & 14.87 & 6.35 & 8.63 & 11.18 & 2012 \\
\hline 52.77 & 0.96 & 2.02 & 15.64 & 8.48 & 13.25 & 12.42 & 2013 \\
\hline 50.12 & 0.92 & 2.33 & 13.43 & 8.59 & 13.66 & 11.19 & 2014 \\
\hline 50.33 & 0.95 & 2.56 & 13.36 & 8.59 & 13.66 & 11.21 & 2015 \\
\hline 50.49 & 1.02 & 2.58 & 11.98 & 9.62 & 13.62 & 11.67 & 2016 \\
\hline 35.54 & 1.01 & 2.06 & 4.97 & 5.29 & 10.42 & 11.79 & 2017 \\
\hline 28.96 & 0.59 & 1.87 & 10.16 & 4.58 & 5.07 & 6.69 & المتوسط \\
\hline 100 & 2.04 & 6.45 & 35.08 & 15.81 & 17.51 & 23.11 & $(\%)$ \\
\hline
\end{tabular}

المصدر: جُمعت وحُسبت من وزارة الزر اعة واستصلاح الار اضي، مديرية الزر اعة بشمال سيناء، سجلات قسم الفاكهة، بيانات غير منشورة، 2018.

جدول 5.معادلات الإتجاة الزمني العام لتطور المساحات المثمرة لمحصول الزيتون داخل مختلف المراكز الإدارية وجملة محافظة شمال سيناء خلال الفترة 2000 -2017.

\begin{tabular}{|c|c|c|c|c|}
\hline $\mathbf{F}$ & 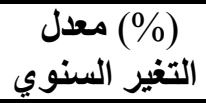 & المعادلات & المراكز الإدارية & المعادلة \\
\hline ***119.9 & 10.5 & $\begin{array}{c}\hat{\mathbf{Y}}=0.009+0.703 \mathbf{T}_{\mathbf{i}} \\
(0.01) \quad(10.9)^{* *}\end{array}$ & بئر العبد & 5 \\
\hline${ }^{* *} 42.9$ & 16.9 & $\begin{aligned} \hat{\mathbf{Y}}= & -3.14+0.86 \mathbf{T}_{\mathbf{i}} \\
& (-2.2)^{*} \quad(6.5)^{* *}\end{aligned}$ & رفح & 6 \\
\hline ***39.9 & 9.2 & $\begin{aligned} \hat{\mathbf{Y}}= & 0.53+0.42 \mathbf{T}_{\mathbf{i}} \\
& (3.1)^{* *}(2.8)^{*}\end{aligned}$ & الثيخ زويد & 7 \\
\hline 7.8 & 4.6 & $\begin{array}{c}\hat{\mathbf{Y}}=5.71+0.47 \mathbf{T}_{\mathbf{i}} \\
(3.1)^{* *} \\
(2.8)^{*}\end{array}$ & العريش & 8 \\
\hline${ }^{* *} 13.4$ & 5.7 & $\begin{array}{c}\hat{\mathbf{Y}}=0.851+0.107 \mathbf{T}_{\mathbf{i}} \\
(2.7)^{*} \quad(3.7)^{* *}\end{array}$ & الحسنة & 9 \\
\hline **37.9 & 6.6 & $\begin{array}{c}\hat{\mathbf{Y}}=0.217+0.039 \mathbf{T}_{\mathbf{i}} \\
(3.1)^{* *} \quad(6.2)^{* *}\end{array}$ & نخل & 10 \\
\hline${ }^{* *} 61.6$ & 9.01 & $\begin{array}{c}\hat{\mathbf{Y}}=4.18+2.61 \mathbf{T}_{\mathbf{i}} \\
(1.2) \quad(7.8)^{* *}\end{array}$ & جملة العينة & 11 \\
\hline
\end{tabular}

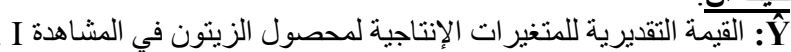

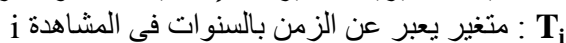
$18 \ldots \ldots \ldots \ldots . . . . . . .261=\mathbf{i}$ المصدر: جُمعت وحُسبت من الأرقام الواردة بالجدول رقم 4. 
جدول 5 معادلـة الاتجـاه الزمنـي العـام لتطـور المسـاحة

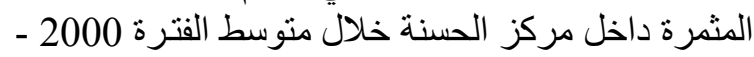
2017، حيث تشير تقدير ات المعادلة رقم (9) اند ان المساحة

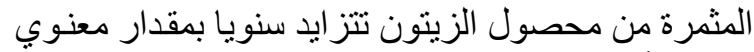

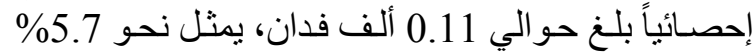
من المتوسط العام خلال نفس الفترة.

تظور المساحة المثمرة لمركز نخل

ينبين من الأرقام الواردة بجدول 4 أن المساحة المثمرة

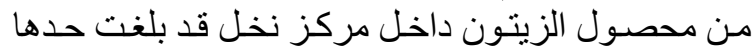

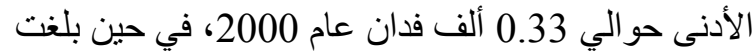

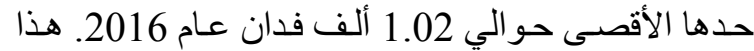

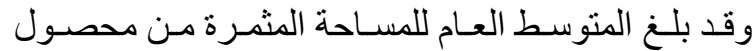

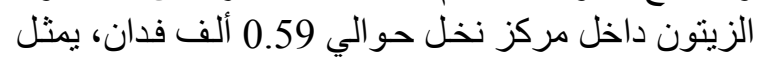
نحو 2.04\% من جملة المحافظة.

ويتضـح مـن جـول 5 معادلـة الاتجـاه الزمنــي العـام

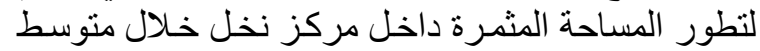

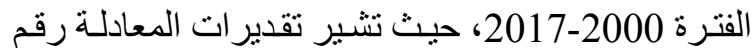

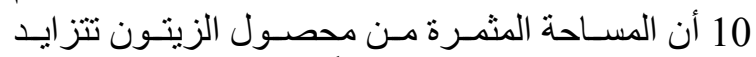

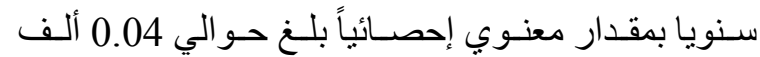

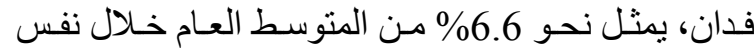

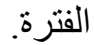

\section{تطور المساحة المثمرة لجملة المحافظة}

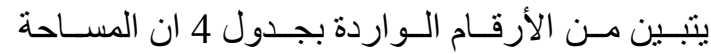

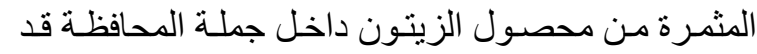

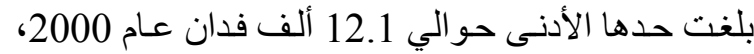
في حين بلغت حدها الأقصى حو الي 52.8 ألف فدان عام 2013

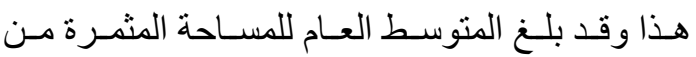

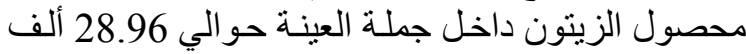

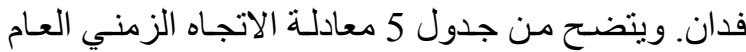

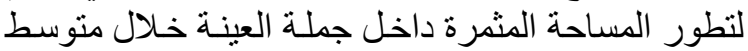

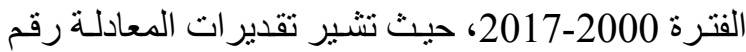

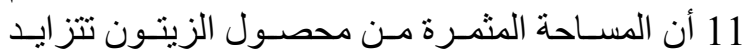

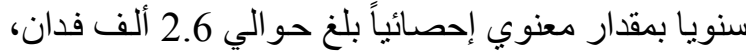
يمثل نحو 9.01\% من المتوسط العام خلال نفس الفترة.

\section{اختيار عينة الدراسة في محافظة شمال سيناء}

اعتمد الباحث في در استه على جمهع بيانـات ميدانيـة

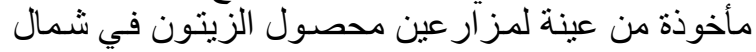

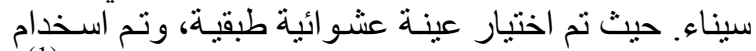

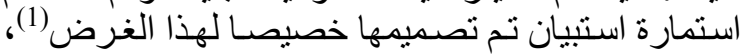

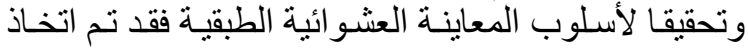

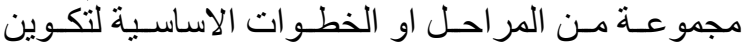
مجتمع العينة وذللك علي النحو النتالي:
يتضح من جدول 5 معادلة الاتجاه الزمني العام لتطور

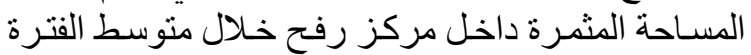

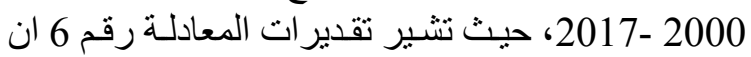

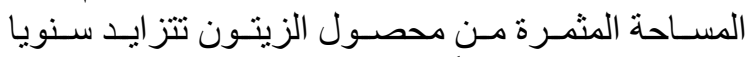

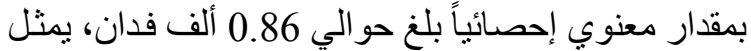
نحو 16.9\% من المنوسط العام خلال نفس الفترة.

\section{تطور المساحة المثمرة لمركز الثيخ زويد}

يتبين من الأرقام الواردة بجدول 14 ان المسـاحة المثمرة

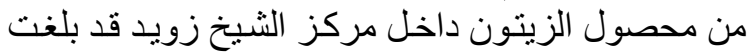
حدها الأدنى حو الي 1.7 ألف فدان عام دان 2000، في في حين

بلغت حدها الأقصى حوالي 9.6 ألف فدان عام 2016. وقد بلغ المتوسط العام للمسـاحة المثمرة من محصول

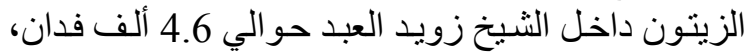
يمثل نحو 15.8\% من جملة المحافظة.

يتضح من جدول 5 معادلة الاتجاه الزمني العام لتطور

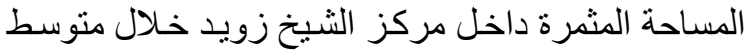

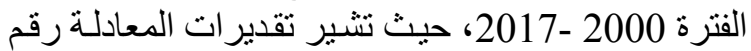

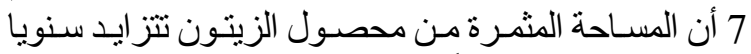
بمقدار معنوي إحصائياً بلغ حو الي 0.42 ألف فئن فدان، يمثنل نحو 9.2\% من المتوسط العام خلال نفس الفترة.

\section{تظور المساحة المثمرة لمركز العريش}

تبين من الأرقام الو اردة بجدول 4 أن المساحة المثمرة

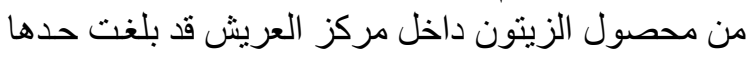

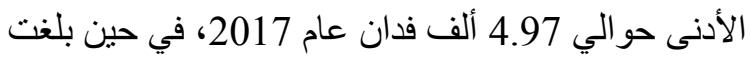

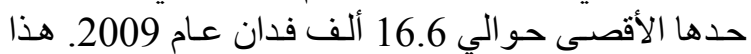

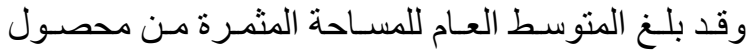
الزيتون داخل مركز العريش حو الي 10.2 ألف فـدان، يمثل نحو 35.1\% من جملة المحافظة.

يتضح من جدول 5 معادلة الاتجاه الزمني العام لتطور

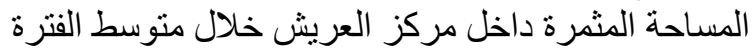

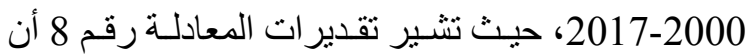

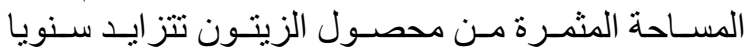

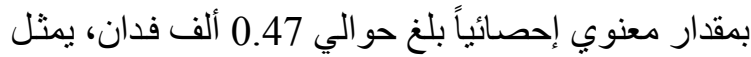
نحو 4.6\% من المتوسط العام خلال نفس الفترة.

\section{تطور المساحة المثرة لمركز الحسنة}

يتبين من الأرقام الواردة بجدول 4 ان المسـاحة المثمرة

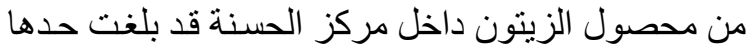

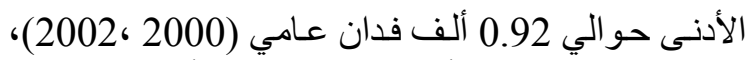

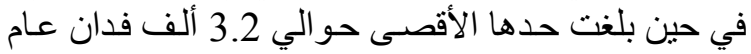

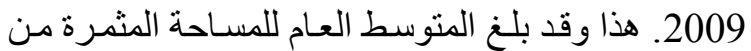

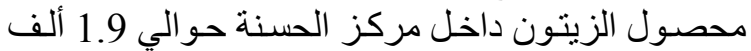

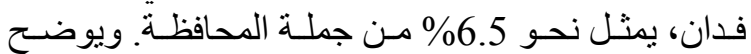


بالنسبة لعدد الحائزين و البالغ حو الي 759 حسائز ا، يمثل نحو 12\% من جملة عدد الحائزين.

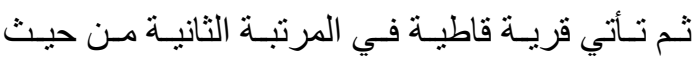

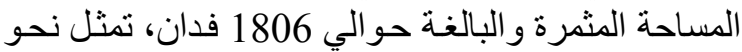

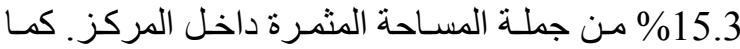

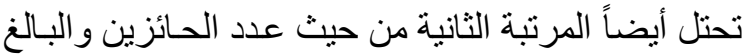

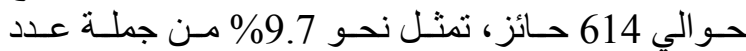

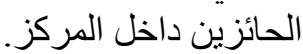

\section{اختيار قري مركز العريش}

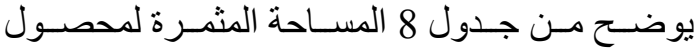
الزيتون و عدد الحائزين لاهم قري مركز العريش بشمال

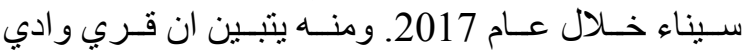

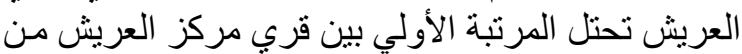

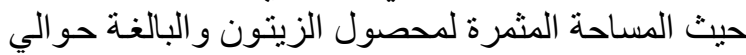

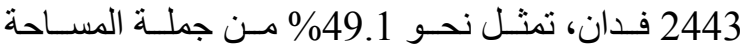

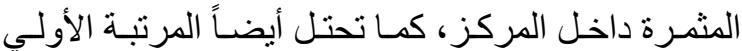

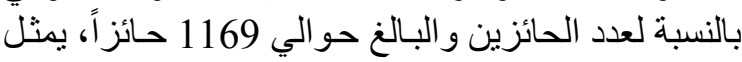

نحو 59.1\% من جملة عدد الحائزين داخل المركز.

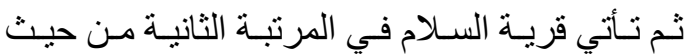

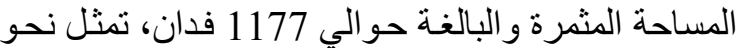

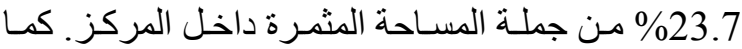

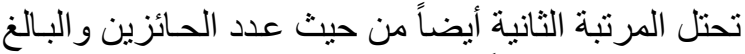

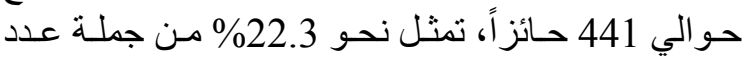

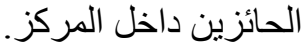

\section{تحديد حجم العينة بشمال سيناء}

تم تقدير حجم العينـة الاجمـالي و البـالغ حـوالي 300

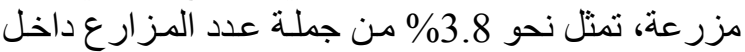

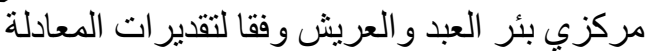

$$
\mathrm{n}=\frac{\mathrm{N}}{(\mathrm{N}-1) \mathrm{B}^{2}+1}
$$

حيث أن:

n

= جملة مجتمع الحائزين لمحصول الزيتون موضع الدراسة. = B

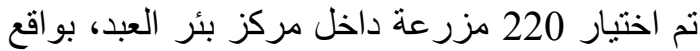

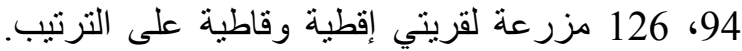

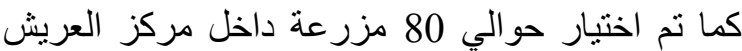

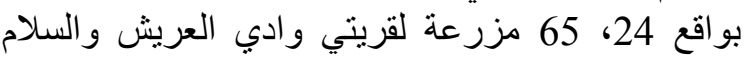

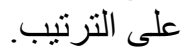

اختيار مراكز العينة بشمال سيناء

يتضح من جدول 6 الأهمية النسبية للمسـاحة المثمرة

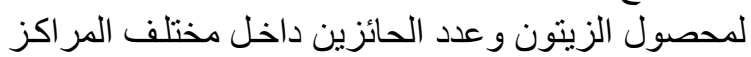

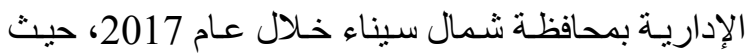

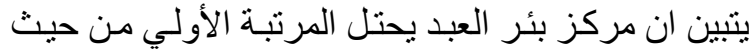

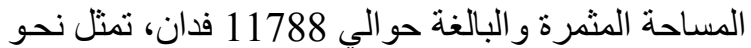

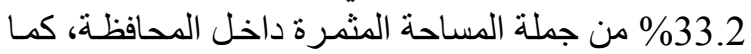
يحتل أيضاً المرنبة الأولي من حيث عدة الحدة الحائزين و البالغ

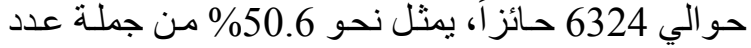

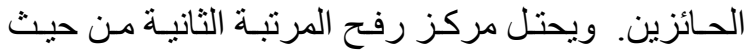

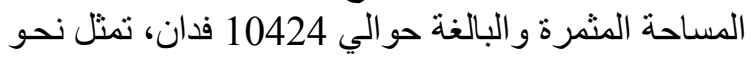

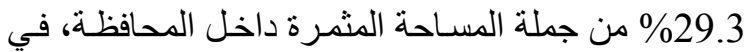
حين تحتل المرتبة الرابعة من حيث عدد الحائزين و البالغ الغئ

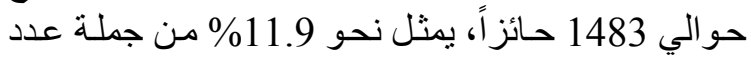

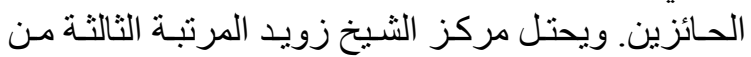
حيث المساحة المثرة و البالغة حو الي 5290 فدانئ

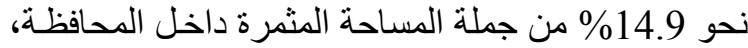

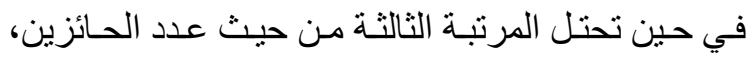
بأهمية نسبية بلغت نحو 12.8\% من جملة عدد الحائزين. أما مركز العريش فقد احتل المرتبة الرابعة من حيث

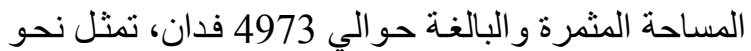

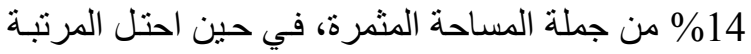

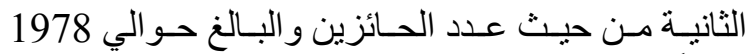
حائز أ، يمثل نحو 15.8\% من جملة عدد الحائزين. ويحتل

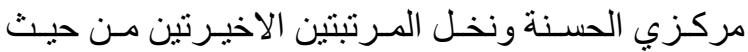

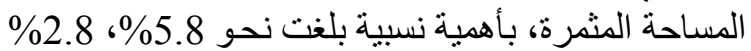

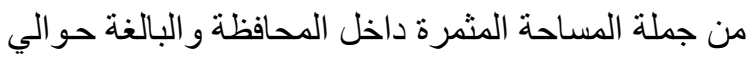

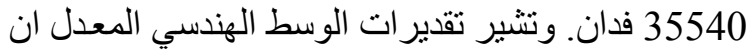

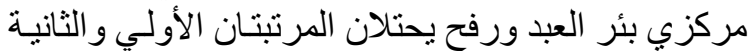

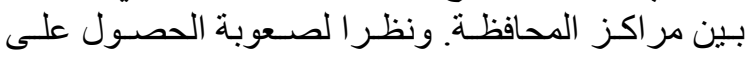

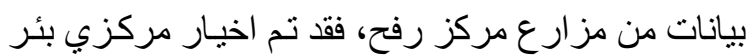

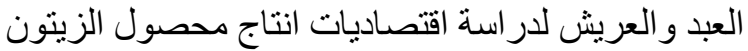
في شمال سيناء.

اختيار قري العينة داخل مركزي الدراسة في محافظة

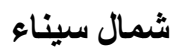

\section{اختيار قري مركز بئر العبد}

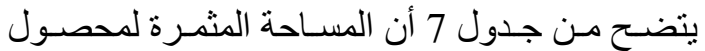

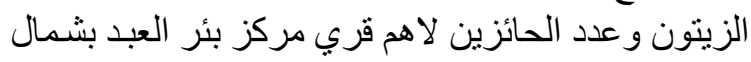

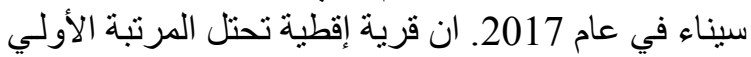

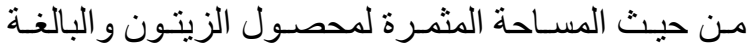

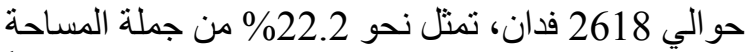
المثمرة داخل المركز ، كمـا تحتـل المرتبـة الأولـي أيضـاً 
جلول 6. الأهمية النسبية للمساحة المثمرة لمحصول الزيتون وعدد الحائزين للمراكز الإدارية بمحافظة شمال سيناء في عام 2017

\begin{tabular}{|c|c|c|c|c|c|}
\hline \multirow{2}{*}{ متوسط الحيازة } & \multicolumn{2}{|c|}{ عدد الحائزين } & \multicolumn{2}{|c|}{ المساحة المثرة } & \multirow{2}{*}{ الادراية } \\
\hline & $(\%)$ & (حائز) & $(\%)$ & (ف) & \\
\hline 1.86 & 50.62 & 6324 & 33.17 & 11788 & بئر العبد \\
\hline 7.03 & 11.87 & 1483 & 29.33 & 10424 & رفح \\
\hline 3.31 & 12.78 & 1596 & 14.88 & 5290 & ش زويد \\
\hline 2.51 & 15.83 & 1978 & 13.99 & 4973 & العريش \\
\hline 2.36 & 6.99 & 873 & 5.79 & 2056 & الحسنة \\
\hline 4.22 & 1.91 & 239 & 2.84 & 1009 & نخل \\
\hline 2.84 & 100 & 12493 & 100 & 35540 & جملة \\
\hline
\end{tabular}

جدول 7. المساحة المثمرة لمحصول الزيتون وعدد الحائزين لأهم قرى مركز بئر العبد بمحافظة شمال سيناء فى عام 2017

\begin{tabular}{|c|c|c|c|c|c|}
\hline \multirow{2}{*}{ متوسط (الحيازة } & \multicolumn{2}{|c|}{ عدد الحائزين } & \multicolumn{2}{|c|}{ المساحة المثمرة } & \multirow{2}{*}{ بئر العبد } \\
\hline & $(\%)$ & (حائزاً) & $(\%)$ & (ف) & \\
\hline 3.45 & 12.00 & 759 & 22.21 & 2618 & إقطية \\
\hline 2.94 & 9.71 & 614 & 15.32 & 1806 & قاطية \\
\hline 3.47 & 7.97 & 504 & 14.82 & 1747 & المريح \\
\hline 0.94 & 9.36 & 592 & 4.73 & 558 & نجيلة \\
\hline 1.48 & 4.25 & 269 & 5.93 & 699 & رابعة \\
\hline 1.04 & 6.86 & 434 & 3.84 & 453 & 6 أكتوبر \\
\hline 2.48 & 50.16 & 3172 & 66.86 & 7881 & جملة \\
\hline 1.24 & 49.84 & 3152 & 33.14 & 3907 & باقي القري(1) \\
\hline 1.86 & 100 & 6324 & 100 & 11788 & جملة المركز \\
\hline
\end{tabular}

جدول 8. المساحة المثرة لمحصول الزيتون وعدد الحائزين لاهم قري مركز العريش بمحافظة شمال سيناء خلال عام 2017

\begin{tabular}{|c|c|c|c|c|c|}
\hline \multirow{2}{*}{ متوسط الحيازة } & \multicolumn{2}{|c|}{ عدد الحائزين } & \multicolumn{2}{|c|}{ المساحة المثمرة } & \multirow{2}{*}{ قريش } \\
\hline & $(\%)$ & (حائز) & $(\%)$ & (ف) & \\
\hline 2.09 & 59.10 & 1169 & 49.12 & 2443 & وادي العريش \\
\hline 2.67 & 22.30 & 441 & 23.67 & 1177 & السلام \\
\hline 4.69 & 6.62 & 131 & 12.37 & 615 & السبيل \\
\hline 6.55 & 4.10 & 81 & 10.68 & 531 & الطويل \\
\hline 2.34 & 2.53 & 50 & 2.35 & 117 & السكاسكة \\
\hline 1.12 & 3.84 & 76 & 1.71 & 85 & الحفنن \\
\hline 0.11 & 1.41 & 28 & 0.06 & 3 & الصقور \\
\hline 1.00 & 0.10 & 2 & 0.04 & 2 & الميدان \\
\hline 2.51 & 100 & 1978 & 100 & 4973 & جملة \\
\hline
\end{tabular}


الثارحة و المتضمنة في النموذج مجتمعة 10\% يؤدى إلى

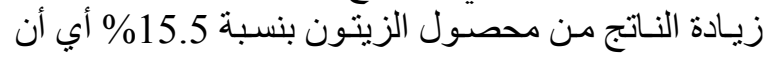

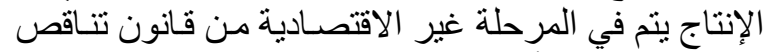

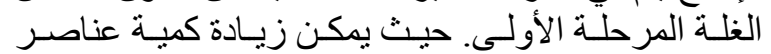

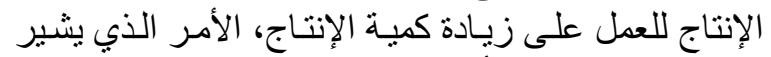

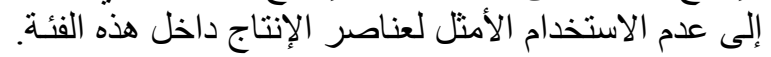

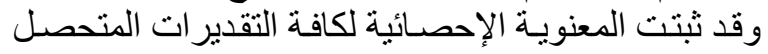

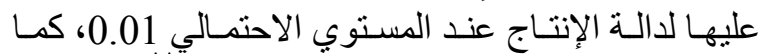

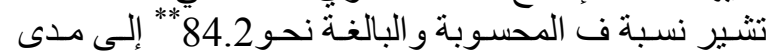
مطابقة النموذج المستخدم لطبيعة البيانات موضع القياس.

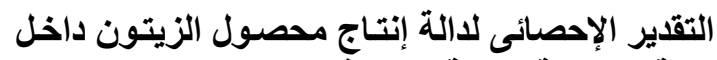
الفئة الحيازية الثانية (3-6 فدانية الثانة

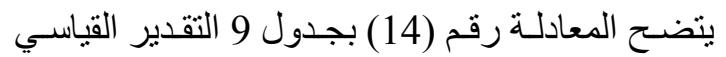
لمعادلة إنتاج محصول المعادلة الزيتون داخل الفئة الحيازيـة الثنانيةً

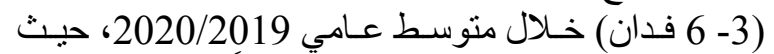
ينتين وجود علاقة طردية مؤكدة إحصائياً بين كمية الإنتاج

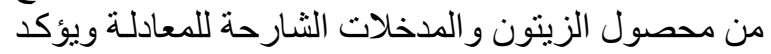

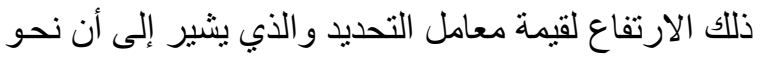

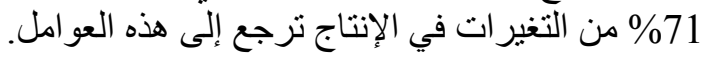

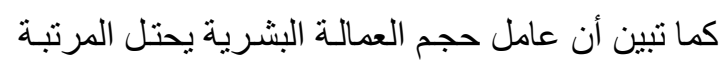

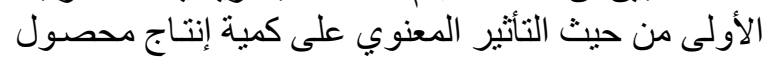

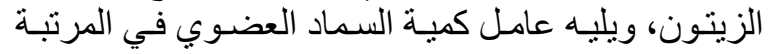

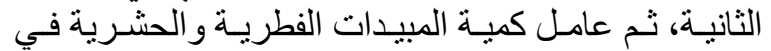

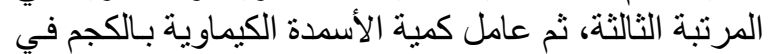

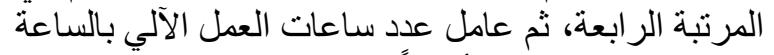

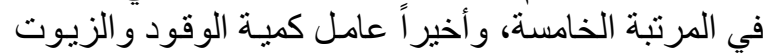
باللتر في المرتبة السادسة.

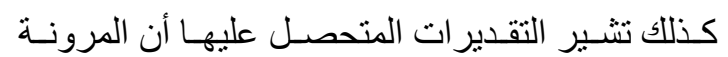

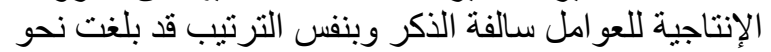

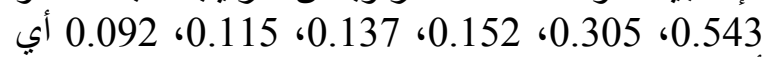

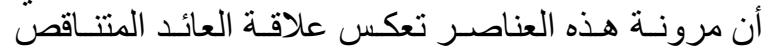

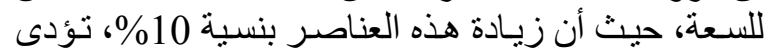

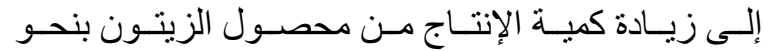

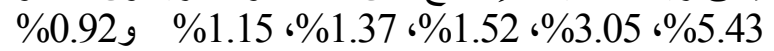

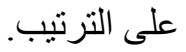

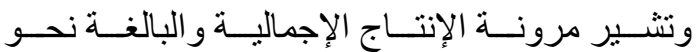

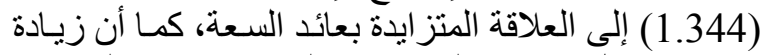

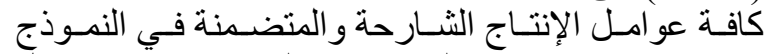

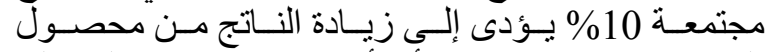

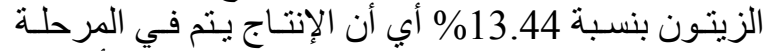

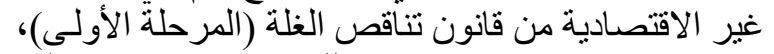

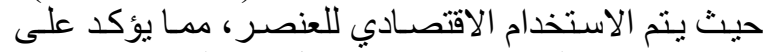

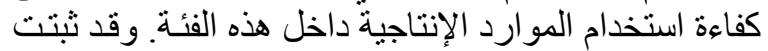

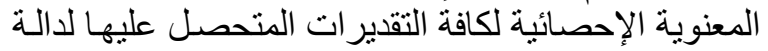

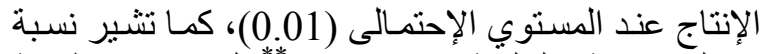

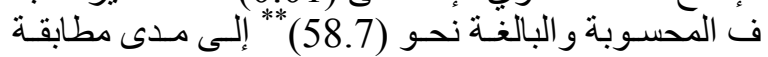
النموذج المستخدم لطبيعة البيانات موضع القياس.
التقدير الإحصائي لدوال إنتاج محصول الزيتون داخل

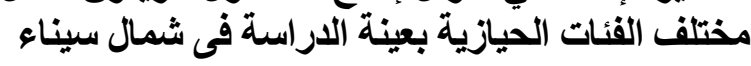

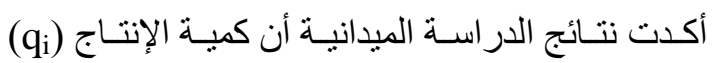

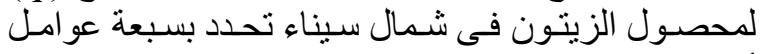

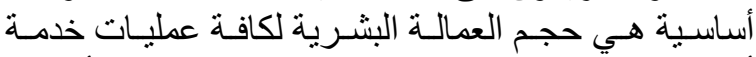

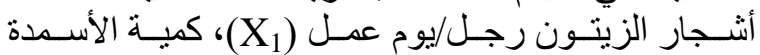

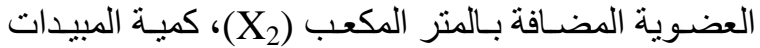
الفطرية والحشرية المستخدمة لوقاية المحصول و والأشجار

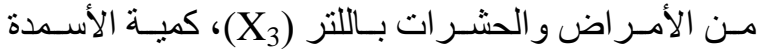

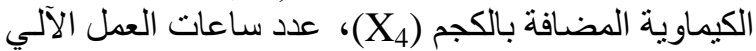

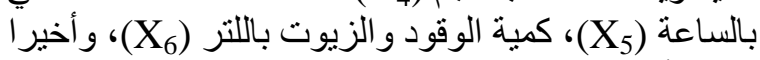

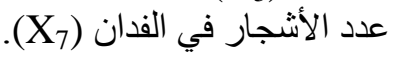

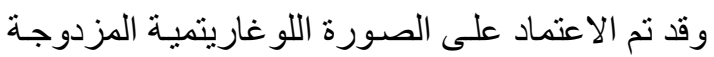

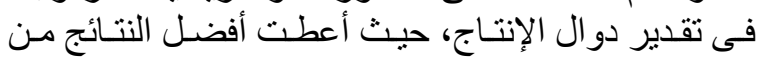

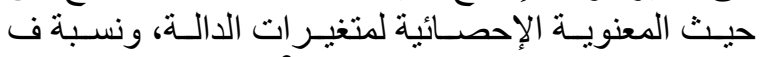
المحسوبة، ومعامل التحديد المعدل (R2).

يوضح جدول 9 نتائج القياس الإحصائي لأهم العوامل التصل

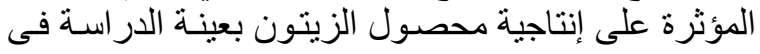

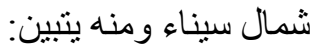

التقدير الإحصائي لدالة إنتاج محصول الزئن الزيتون داخل الفئة الحيازية الأُولى (أقلّل من 3 فدان)

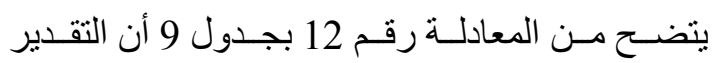

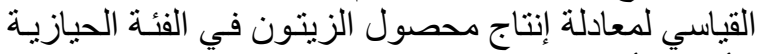

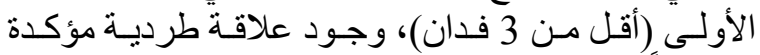

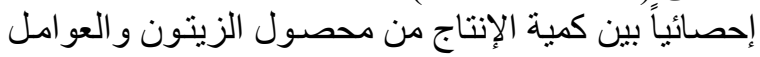

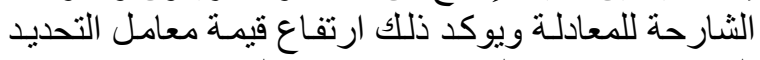

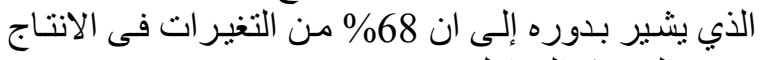

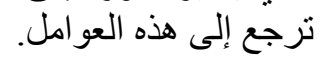

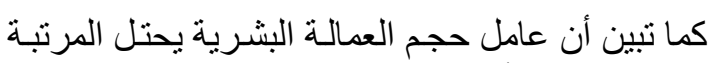

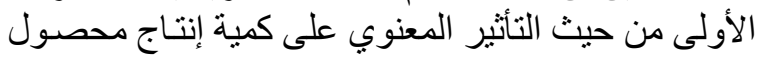

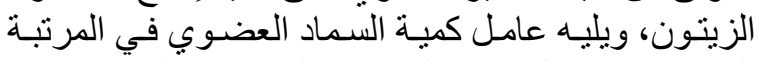

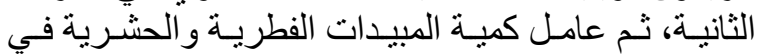

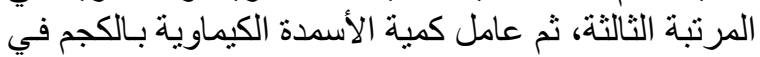

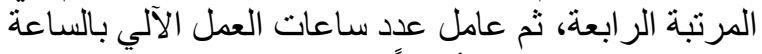

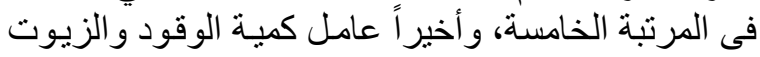

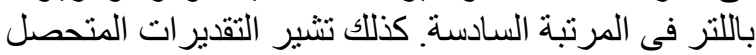

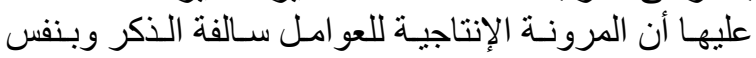

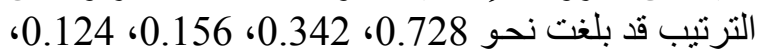

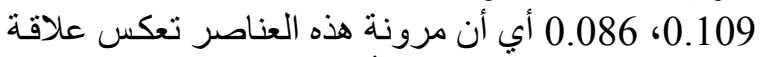

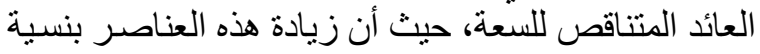

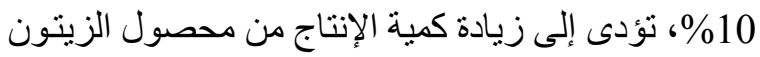

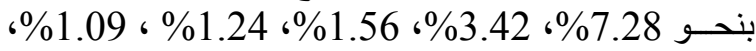
0.86\% على الترتيب.

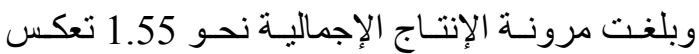
عو ائد متز ايدة السعةد، كمـا أن زيـادة كافـة عو امـل الإنتـاج 
جدول 9. نتائج القياس الإحصائي لأهم العوامل المؤثرة على إنتاجية محصول الزيتون بعينة الدراسة فى شمال سيناء خلال متوسط عامى 2020/2019.

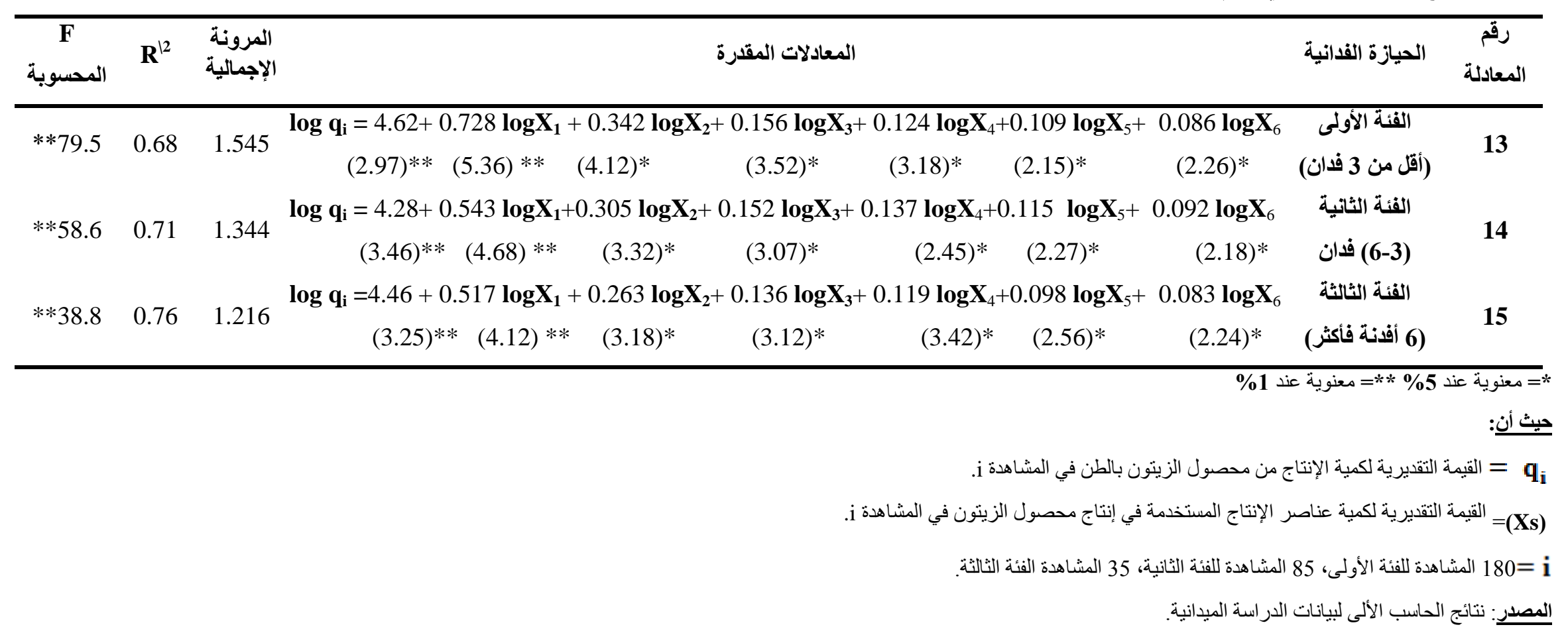


دالة تكاليف الفئة الحيازية الأولي (أقل من 3 فدان)

يتضح من المعادلة رقم 15 بجدول 10 نتائج القياس لزئس

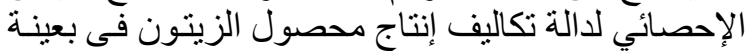

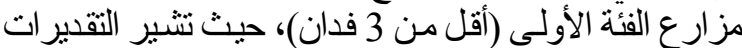

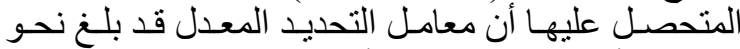

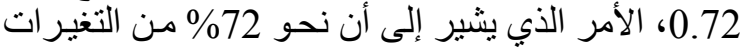

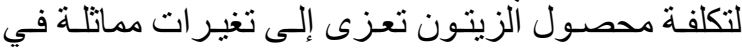

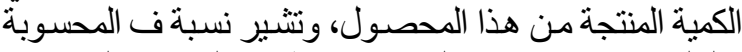

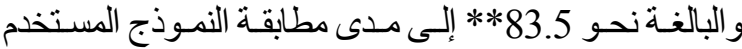
لطبيعة البيانات موضع القياس.

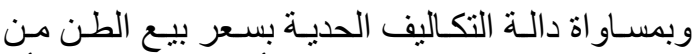

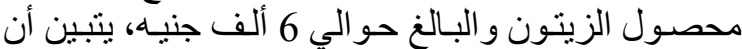

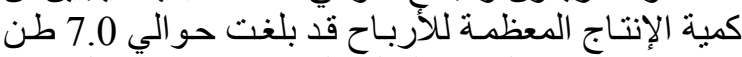

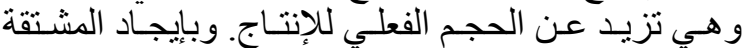

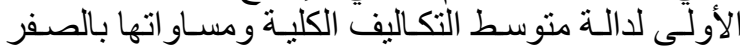

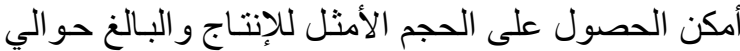

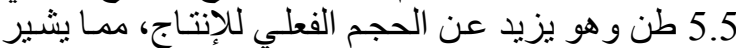
إلى وجود دخل ضائع لمز ار عي هذه الفئة.

\section{دالة تكاليف الفئة الحيازية الثانية (3 -6 فدان)}

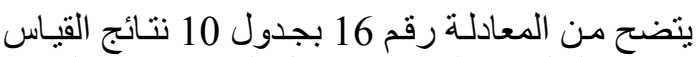

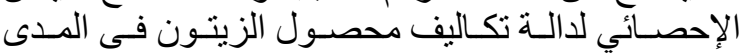

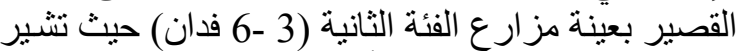

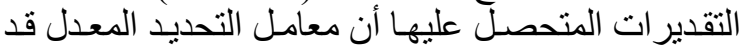

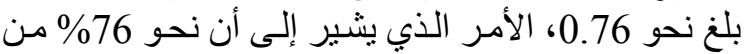

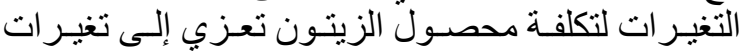

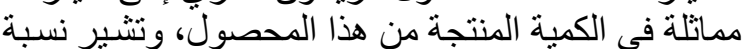

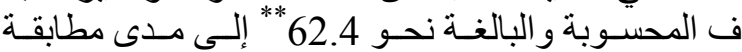

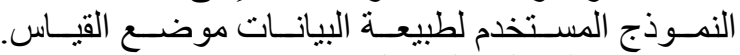

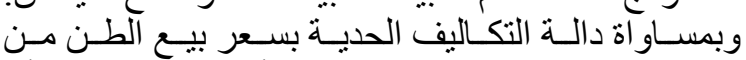

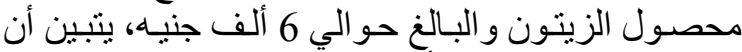

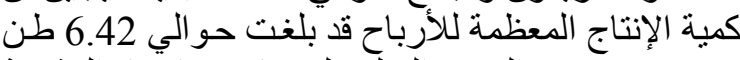

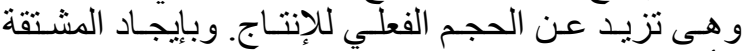

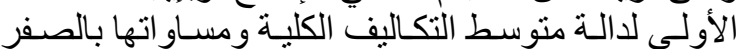

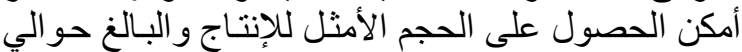

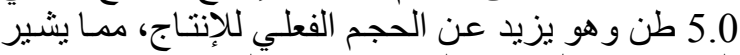
إلى وجود دخل ضائع لمز ارعي هذه الفئة.

\section{دالة تكاليف الفئة الحيازية الثالثة (6فدان فأكثر)}

يتضح من المعادلة رقم 17 بجدول 10 نتائج القياس

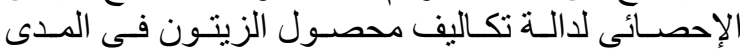

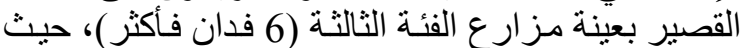

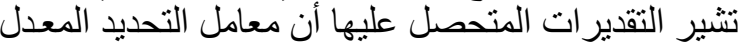

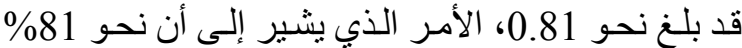

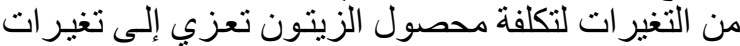

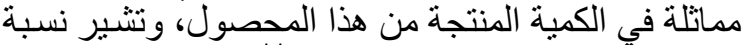

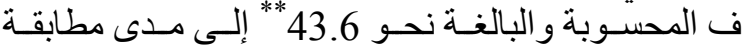

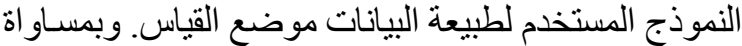

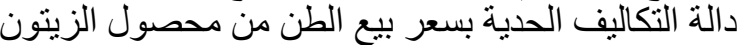
و البالغ حو الي 6 ألف جنياه، ينتين أن كمية الإنتاج المعظمة الزئ
التقدير الإحصائي لدالة إنتاج محصول الزيتون داخل الفئة الحيازية الثُالثة (6 فلثان فأكثر)

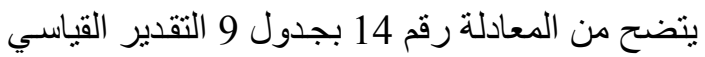
لمعادلة إنتاج محصول الزينون دادئ داخل الفئة الحيازية الثالثة

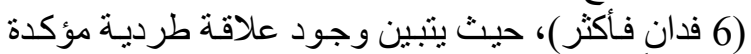

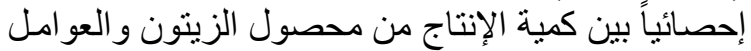

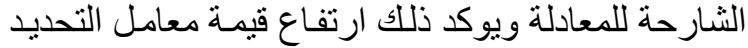
و الذي يشير إلى أن نحو 76\% مـ التغير ات في الإنتاج

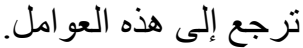

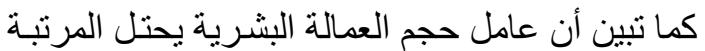

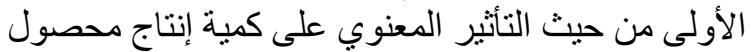

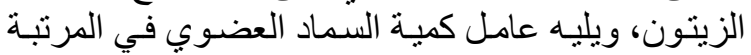

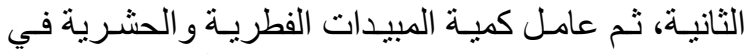

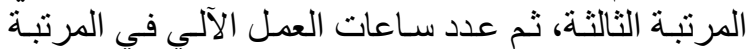

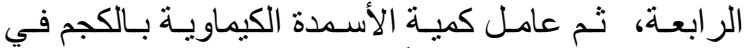

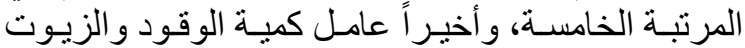
باللتر فى المرتبة السادسة.

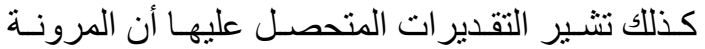

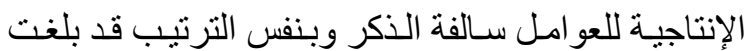

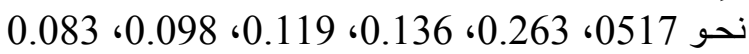
أب أن مرونة هذه العناصر تعكس علاقة العائد المتناقص

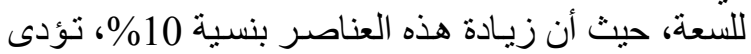

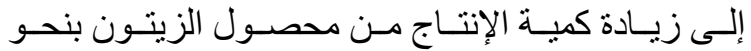

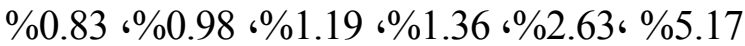

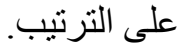

وتشير مرونة الإنتاج الإجمالية والبالغة نحو 1.216 إلى الى

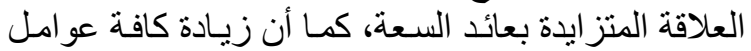

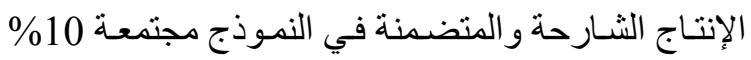

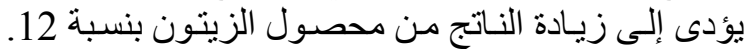

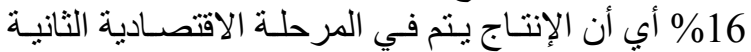
من قانون تناقص الغلة. حيث يتم الاستخدام الاقتصـادي لإني

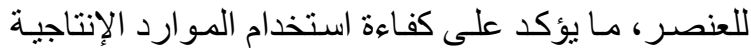

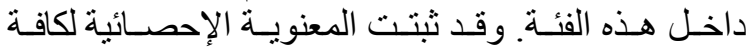

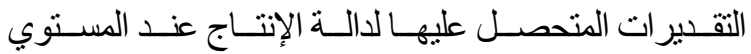

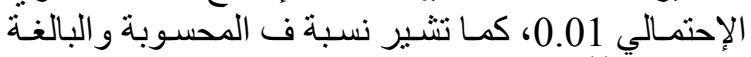

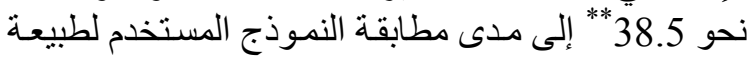

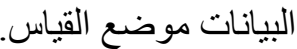

القياس الإحصائي لاوال تكاليف محصول الزيتون فى المدى القصير داخل مختلف الفئات الحيازية الرية بعينة الار اسلة

يعرض جدول 10 النماذج القياسية لدوال التكاليف الإجمالية لمحصول الزيتون داخل مختلف الفئات الحيازية بعينة الدراسة فى المدى القصير بمحافظة شمال سيناء

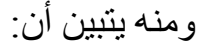


جدول 10. النماذج القياسية لاوال تكاليف إنتاج محصول الزيتون داخل مختلف الفئات الحيازية بعينة الدراسة بمحافظة شمال سيناء خلال متوسط عامي 2020/2019.

\begin{tabular}{|c|c|c|c|c|}
\hline 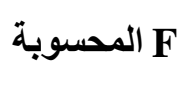 & $\mathbf{R}^{12}$ & النماذج القياسية لاوال التكاليف الإجمالية & الحيازة الفدانية & المعادلة \\
\hline$* * 83.5$ & 0.72 & $\begin{array}{c}\mathbf{T} \mathbf{c i}=5.15+4.25 \mathbf{q}_{\mathbf{i}}-1.15 \mathbf{q}_{\mathbf{i}}{ }^{2}+0.12 \mathbf{q}_{\mathbf{i}}^{3} \\
(3.18)^{*}(6.14)^{* *}(-2.73)^{*}(2.34)^{*}\end{array}$ & 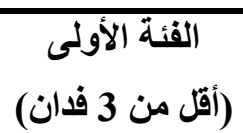 & 15 \\
\hline$* * 62.4$ & 0.76 & $\begin{array}{l}\mathbf{T} \mathbf{c i}=4.5+4.41 \mathbf{q}_{\mathbf{i}}-1.32 \mathbf{q}_{\mathbf{i}}{ }^{2}+0.15 \mathbf{q}_{\mathbf{i}}{ }^{3} \\
(3.75)^{*}(6.52)^{* *}(-2.54)^{* *}(2.48)^{*}\end{array}$ & الفئة الثانية & 16 \\
\hline$* * 43.6$ & 0.81 & $\begin{array}{c}\mathbf{T} \mathbf{c i}=4.91+4.51 \mathbf{q}_{\mathbf{i}}-1.52 \mathbf{q}_{\mathbf{i}}^{2}+0.18 \mathbf{q}_{\mathbf{i}}^{3} \\
(3.42)^{*}(6.69)^{* *} \quad(-2.61)^{*}(2.25)^{*}\end{array}$ & (6 فانة فأكثر ) & 17 \\
\hline \multicolumn{5}{|c|}{ 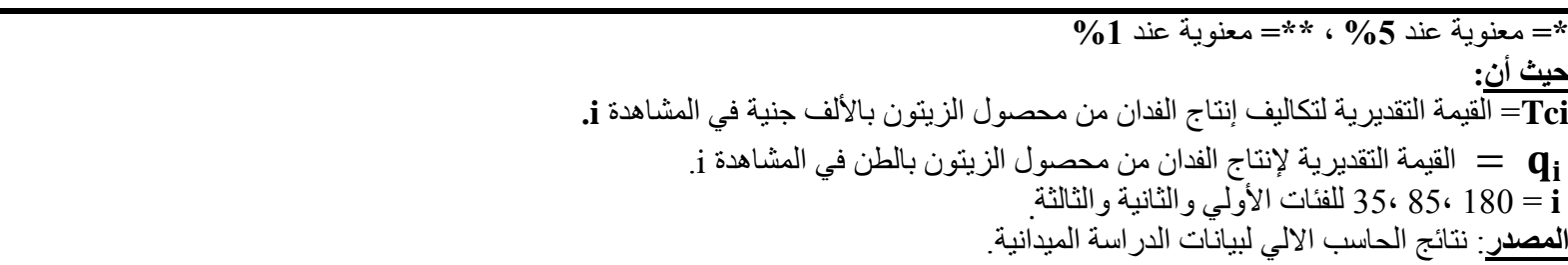 } \\
\hline
\end{tabular}

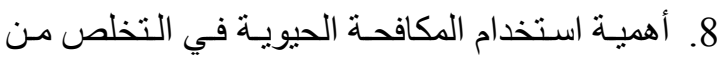

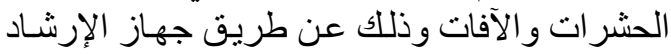

$$
\text { الزر اعي. }
$$

\section{المراجـع}

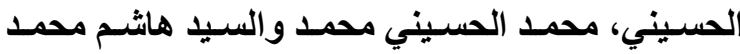

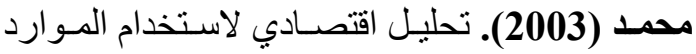

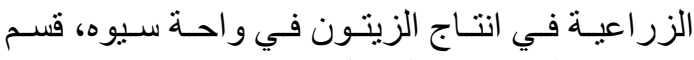

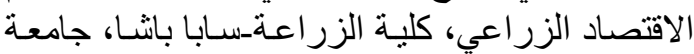
الإسكندرية.

أبو النجـا محمـد علـي عواد (2009). دراسـة اقتصـادية

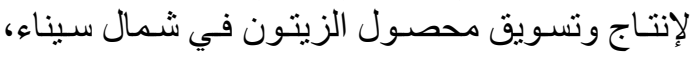

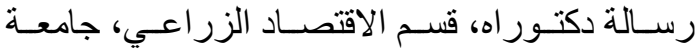
الز قازيق.

وزارة الزراعـة واستصـلاح الأراضـي (2018). مديريـة

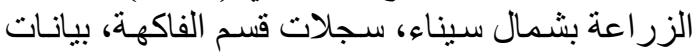

$$
\text { غير منشورة. }
$$

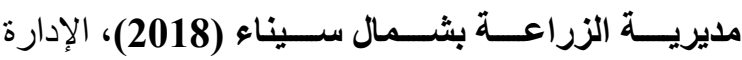
الزراعيـة لمركـز العـريش، ســلات ادارة الفاكهـة، الأدارة

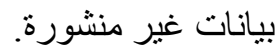

للأرباح قد بلغت حو الي 6.08 طن و هي تزيد عن الحجم

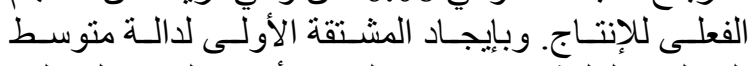

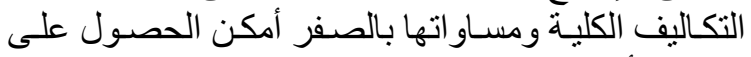

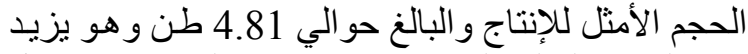

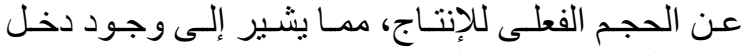
ضائع لمز ارعي هذه الفئة.

التوصيات

1. ضـرورة الإحـلال و التجديد للأشـجار ذات الأعمـار الكبيرة ومنخفضة الإنتاجية.

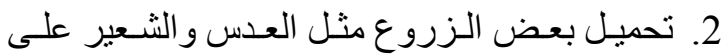

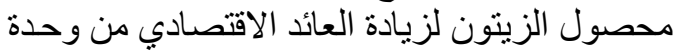

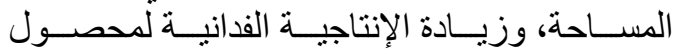
الزينون المحمل بالعدس.

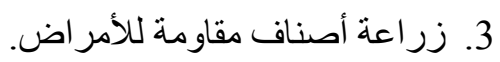

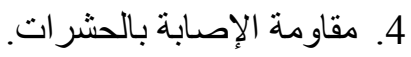

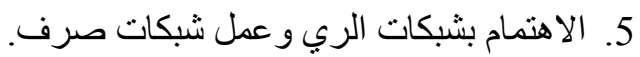

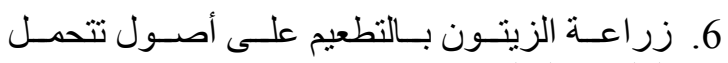
الملوحة العالية.

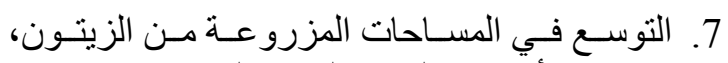
خاصة بالأر اضي الجديدة لزيادة المنتج منه. 


$$
\begin{aligned}
& \text { الملخص العربي } \\
& \text { دراسة اقتصادية لإنتاج وتكاليف محصول الزيتون في محافظة شمال سيناء }
\end{aligned}
$$

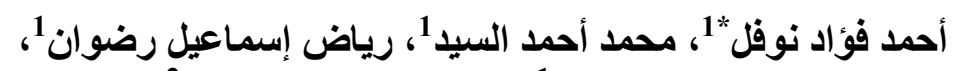

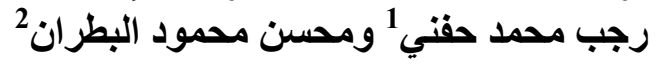

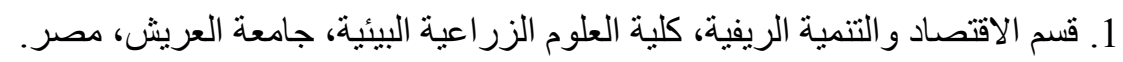

$$
\begin{aligned}
& \text { 2. قسم الاقتصاد الزراعي، كلية الزر اعة، جامعة القاهرة، مصر. }
\end{aligned}
$$

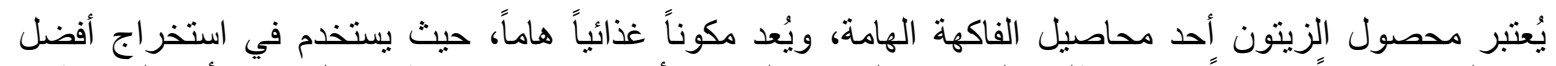

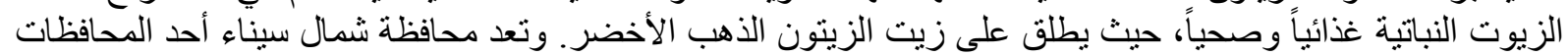

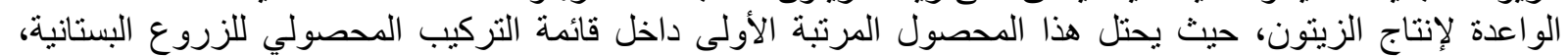

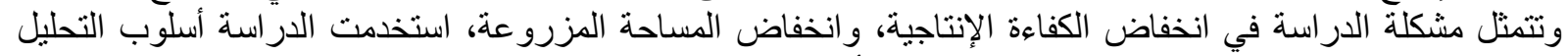

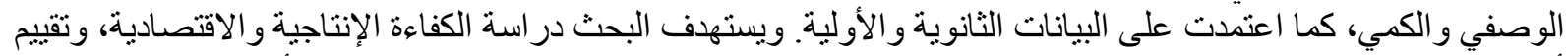

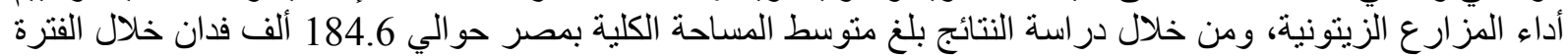

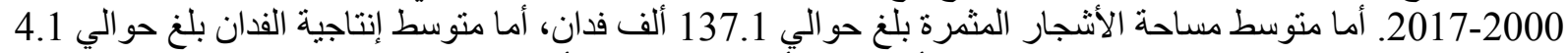

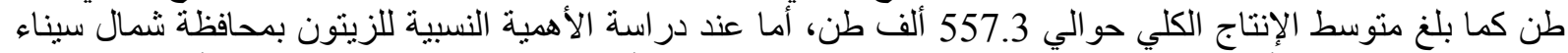

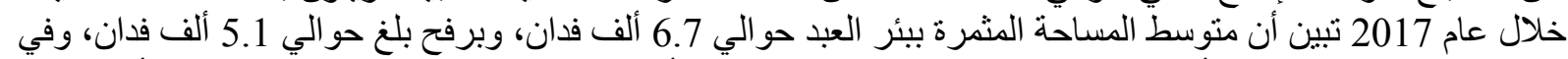

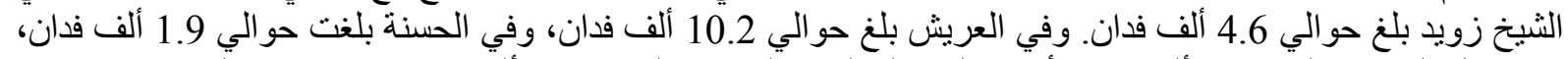

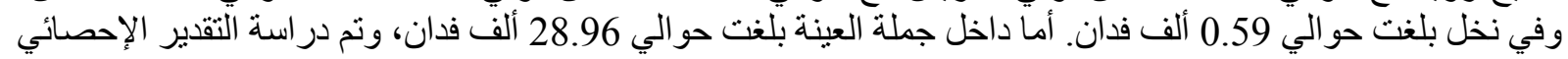

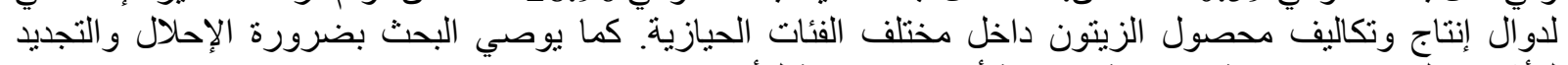

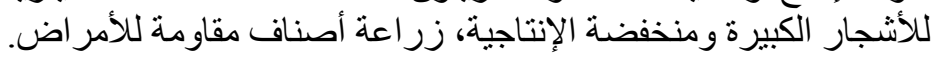
الكلمات الاسترشادية: محصول الزيتون، دراسة اقتصادية، دو ال الإنتاج، دو ال التكاليف ومحافظة شمال سيناء.

أستاذ الاقتصاد الزراعي، كلية الزر اعة ـ الثاطبي، جامعة الإسكندرية، مصر.

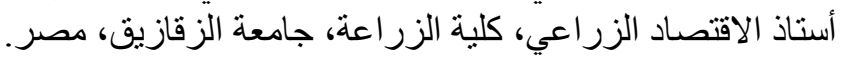

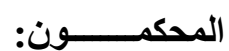
1-أ.د. أحمد أبو اليزيد عبدالحميد

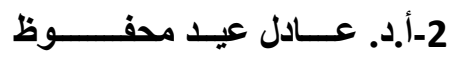


